Phytohormones in Plant Biotechnology and Agriculture 


\section{Phytohormones in Plant Biotechnology and Agriculture}

Proceedings of the NATO-Russia Workshop held in Moscow, 12-16 May 2002

Edited by

\section{Ivana Macháčková}

Institute of Experimental Botany of the

Academy of Sciences of the Czech Republic,

Prague, Czech Republic

and

\section{Georgy A. Romanov}

Institute of Plant Physiology,

Russian Academy of Sciences, Moscow, Russia

SPRINGER-SCIENCE+BUSINESS MEDIA, B.V. 
A C.I.P. Catalogue record for this book is available from the Library of Congress.

ISBN 978-90-481-6472-1ＩSBN 978-94-017-2664-1 (eBook)

DOI 10.1007/978-94-017-2664-1

Printed on acid-free paper

\section{All Rights Reserved}

(C) 2003 Springer Science+Business Media Dordrecht

Originally published by Kluwer Academic Publishers in 2003

Softcover reprint of the hardcover 1st edition 2003

No part of this work may be reproduced, stored in a retrieval system, or transmitted in any form or by any means, electronic, mechanical, photocopying, microfilming, recording or otherwise, without written permission from the Publisher, with the exception of any material supplied specifically for the purpose of being entered and executed on a computer system, for exclusive use by the purchaser of the work. 


\section{TABLE OF CONTENTS}

Preface $\quad$ ix

Acknowledgements $\quad$ xi

Colour plates $\quad$ xiii

\section{Flowering}

Hormonal regulation of plant development in the studies by M. Kh. Chailakhyan In dedication of the $100^{\text {th }}$ anniversary of his birth N. P. Aksenova

The plant hormones: From original concepts to a molecular flowering P. J. Davies

Three roles for gibberellin in flowering

R. King

The role of gibberellin-regulated gene expression during anther and early flower development in tomato

G. W. M. Barendse and K.J.P.T. van den Heuvel

Involvement of gibberellins in development and senescence of rose flowers

N. Zieslin and H.Agbaria

Potato tuberization: evidence for a SD-dependent and a gibberellindependent pathway of induction

J. Bou, A. Virgós, J. Martínez-García and S. Prat

Investigation on the chemical nature of flower-inducing factor(s) in short-day plant Pharbitis nil

A. Tretyn, K. Glowacka, K. Kasprzak, E. Galoch, N. Kulikowska-Gulewska and J. Kopcewicz

Occurrence and putative role of melatonin in plants

J. Kolář and I. Macháčková

Informational signalling in stem apical meristems of plants during transition to flowering

E. L. Milyaeva and V.V. Nikiforova 


\section{Cytokinins}

Cytokinin as a regulatory factor for yield and biomass distribution in crop plants

T. Schmülling, T. Werner, M. Riefler, E. Krupková, I. Bartrina, Y. Manns and H. Dorthay

Exploitation of mechanisms regulating cytokinin levels to improve cereals

M. Kamínek, B. Šolcová, M. Trčková, V. Motyka, S. Daskalová and M.C. Elliott

Primary alcohols, substrates for phospholipase D-catalyzed transphosphatidylation, suppress the cytokinin action

G. A. Romanov, I.A.Getman, Yu.P. Bolyakina, N.Yu. Rakova, J.J. Kieber and T. Schmülling

\section{Auxins}

Physiological and molecular genetic aspects of auxin transport: recent developments

D. A. Morris and E. Zažímalová

Role of calcium ions in plant growth and mechanism of IAA action

S. S. Medvedev and V. Markova

Transgenic plants of modified auxin status and enhanced productivity R. K. Salyaev, N.I. Rekoslavskaya, S. Mapelli, V.M. Sumtsova, N.V. Pakova and A.A. Truchin

Cell wall extensibility changes by hormonal and non-hormonal factors

\section{Complex hormonal regulation of developmental processes}

Hormonal regulation of Crassulacean acid metabolism (CAM) and inter-organ stress signal transduction

Vl. V. Kuznetsov, A.G. Kruglova, O.I. Molodyuk, V.V. Karyagin, A.B Meshcheryakov, V.V. Ragulin, V. Yu. Rakitin, V.P. Kholodova

Monomeric G-proteins and MAP kinases are involved in ethylene signal transduction

I. E. Moshkov, G. V. Novikova, L. A. J. Mur, A. R. Smith and M. A. Hall 
Rosette leaf senescence in wild type and ethylene-insensitive mutant of Arabidopsis thaliana during inflorescence and fruit development

Sergiev, D. Todorova, V. Alexieva, E. Karanov, A. Smith and M.A. Hall

Involvement of hormones in the increase in plant productivity induced by localised fertilizer placement

G. R. Kudoyarova, I.I. Ivanov, V.K. Trapeznikov and S.Yu. Veselov

Distribution of phytohormones among different plant organs determines the development of competitive sinks in radish plants

N. Bukhov, A. Kotov, S. Maevskaya, E. Egorova and I. Drozdova

Hormonal regulation of somatic embryogenesis in maize

Yu. I. Dolgikh, T. N. Pustovoitova and N. E. Zhdanova

Phytohormones and cytoskeleton

N. L. Klyachko and M.A. Erokhina

Regulation of male gametophyte development in Angiosperma: the role of intracellular $\mathbf{p H}$ and transmembrane chloride transport

I. P. Yermakov, N.P. Matveyeva and D.S. Andreyuk

Activity of racemase and appearance of N-malonyl-D-tryptophan during osmotic stress and drought conditions

N. I. Rekoslavskaya, O. V. Yurieva, T. V. Kopytina, R. K. Salyaev, B.A.

Shainyan and S. Mapelli 


\section{PREFACE}

Phytohormone research is a crucially important area of plant sciences. Phytohormones are one of the key systems integrating metabolic and developmental events in the whole plant and the response of plants to external factors. Thus, they influence the yield and quality of crops. During the last decade we have slowly begun to understand the molecular mechanisms underlying phytohormone action, largely as a result of the rapid developments that have been made internationally in the field of plant molecular genetics. Putative receptor proteins for ethylene (199395), brassinosteroids (1997) and cytokinins (2001) have been identified and the genes that encode them cloned. Primary response genes and elements of hormonal signal transduction have also been identified for most known phytohormones. There is now little doubt that phytohormones, like their animal counterparts, function as signal molecules and create a signalling network in the whole plant organism.

The in vivo activity of hormones depends, among other things, on their rate of biosynthesis and metabolism, and on their transport into and out of target cells. Consequently, genes and enzymes involved in these processes are of particular interest. In recent years a number of genes encoding enzymes for the synthesis, modification and degradation of different phytohormones have been cloned and identified, as have genes encoding proteins involved in phytohormone transport and its regulation. Some classes of phytohormone have been shown to participate in stress reactions and can increase the resistance of plants to unfavorable environmental factors. All the developments mentioned above provide potentially powerful tools for the creation of new plant forms with desirable properties for modern biotechnology, agriculture and horticulture. Indeed, new transgenic or mutant plants have recently been produced showing altered hormonal status or sensitivity. Such plants are now under intensive investigation in laboratories in many parts of the world.

Recent advances in phytohormone research and practical applications of this research were discussed at the NATO-Russia Advanced Research Workshop "Phytohormones in Plant Biotechnology and Agriculture", held in May 2002 at the Institute of Plant Physiology of the Russian Academy of Sciences, Moscow. The Workshop was dedicated to the centenary of the birth of the famous Russian plant physiologist, Academician Mikhail Chailakhyan (1902-2002). Chailakhyan pioneered investigations into the hormonal regulation of flowering, and of the flowering hormone "florigen". He quickly appreciated the potential for the application of the results of phytohormone research in agriculture and horticulture, and was one of the first to use gibberellin treatments in seedless grape production.

This book contains papers written by lecturers and selected participants in the Workshop. The main topics centre around: molecular aspects of phytohormone action and transport; phytohormones and flowering; phytohormones and stress; the 
use of phytohormones in plant biotechnology and agriculture; and the use of transgenic plants. In our opinion, the book reflects not only current progress and achievements in phytohormone research, but also the high degree of international cooperation and friendship that were a feature of the Workshop.

We would like to sincerely thank the North Atlantic Treaty Organization, the sponsors of the workshop, for their support. This enabled the workshop to achieve a high international standard. We are especially grateful to the NATO Scientific Affair Division, represented by Dr. Alain Jubier who personally attended the first day of the

Workshop. We also acknowledge with thanks the Russian Ministry of Industry, Science and Technology and Professor Nikolaus Amrhein (ETH Zurich, Switzerland) for their financial support and Professor Vladimir Kuznetsov, Director of the Moscow' Institute of Plant Physiology for providing all necessary facilities for workshop organisation.

Ivana Macháčková and Georgy Romanov, Co-Directors of the Workshop 


\section{ACKNOWLEDGEMENTS}

Financial contribution of the following companies, which enabled to publish these Proceedings, is gratefully acknowledged:

Spectronex, spol. s r.o.

Nad Ostrovem 1119/7

Praha 10

BioTech a.s.

V Ochozu 20

Praha 10

Pragolab s.r.o.

Kovářská 4

Praha 9
BIO-RAD spol. s r.o.

Černická 772/19

Praha 4

P-LAB a.s.

Ř́čanská 10

Praha 10

AMEDIS, spol. s r.o.

Bobkova 786

Praha 9

Further, the invaluable help of Marie Kapounová, Dr. Jan Martinec, Dr. Eva Zažímalová and Mgr. Lenka Vítová of the Institute of Experimental Botany CAS, Prague in preparation of this book is gratefully acknowledged. 


\section{COLOUR PLATES}

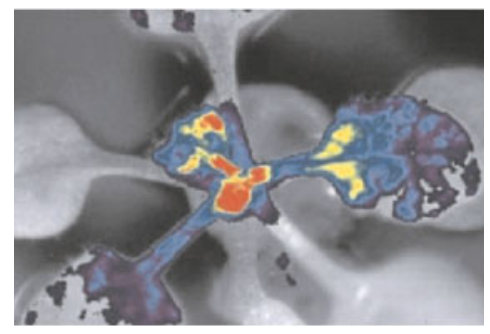

Davies et al.: Figure 13. The false-colour image of light emitted by transgenic Arabidopsis plants containing the firefly luciferase (LUC) reporter gene coupled to the AtGA20ox1 promoter demonstrates that the GA20ox1 gene is expressed most strongly in the shoot apex and in young developing leaves. (From P. Hedden, IAACR-BBSRC annual report, 2000.)
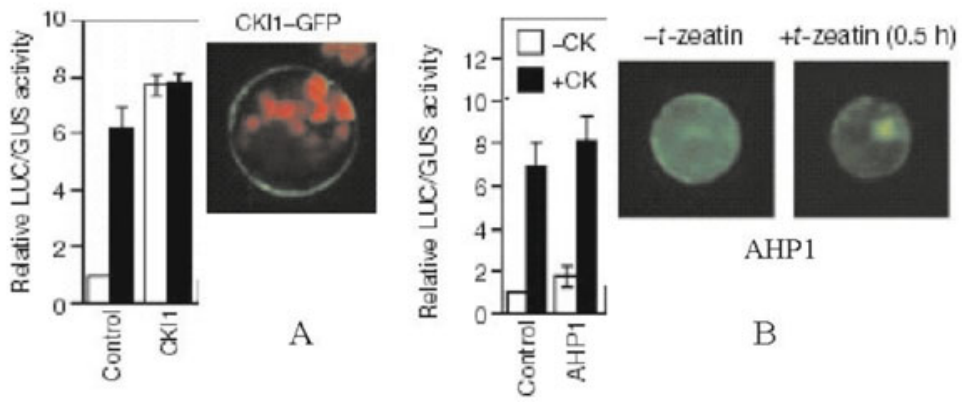

Davies et al.: Figure 18. (A) Left: Cytokinin signalling is initiated by CKI1, a histidine protein kinase receptor, in the absence of cytokinin. Protoplasts were cotransfected with CKII and the ARR6-LUC reporter gene and the luciferase activity recorded. Right: The CKII (as detected in protoplasts transfected with CKI1-GFP) is localized at the plasma membrane. (B) Cytokinin signalling intermediate AHP acts as a shuttle between the cytoplasm and nucleus in cytokinin signalling. Left: Overexpression of AHP (as detected by the ARR6-LUC reporter) does not affect cytokinin signalling; $C K$ is still needed. However $C K$ causes a relocation of AHP (as detected in protoplasts were transfected with AHP1-GFP) to the nucleus (right). (From Hwang and Sheen, 2001.) 
xiv
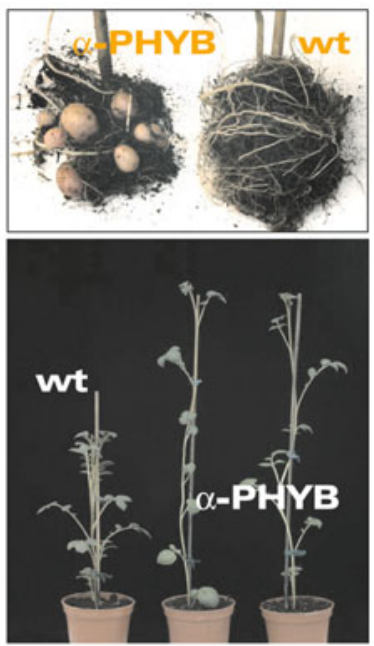

Bou et al.: Figure 1. Slender phenotype and tuberization response of the antisense phyB lines. Only the phyB lines tuberize in $L D$. These plants have paler leaves and anelongated stems due to increase internode length.
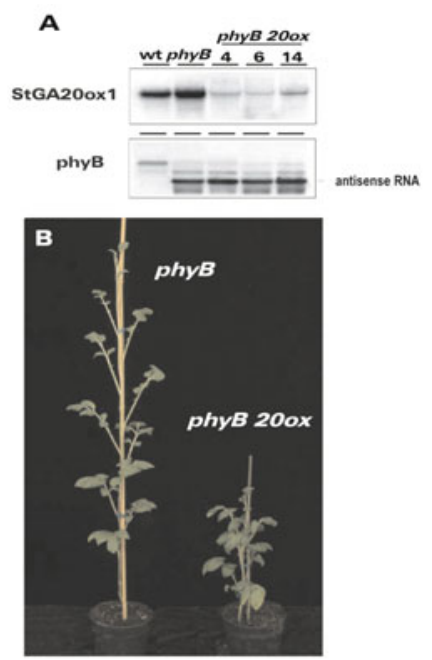

Bou et al.: Figure 4. Phenotype of the phyB $200 x$ antisense lines. (A) Downregulated expression of the phyB and StGA20oxl transcripts in the phyB $200 x$ lines. (B) Dwarf phenotype of the phyB 20ox mutants. The leaves of these plants show still a pale phenotype, which indicates that this trait is not dependant on Gas. 